\title{
Species diversity and ethnobotanical inventory of wild flora used by the folk community of Shinghar Balochistan, Pakistan
}

\author{
ANWAR UL HAQ, SHAZIA SAEED`, ALIA AHMED \\ Department of Botany, University of Balochistan. Sariab Road, Quetta, Balochistan, Pakistan. •email: shazia_botany@yahoo.com
}

Manuscript received: 30 July 2021. Revision accepted: 16 August 2021.

\begin{abstract}
Haq AU, Saeed S, Ahmed A. 2021. Species diversity and ethnobotanical inventory of wild flora used by the folk community of Shinghar Balochistan, Pakistan. Nusantara Bioscience 13: 148-157. Upper Suleiman Mountain of Shinghar Balochistan, Pakistan, is little known by outsiders, and the structural and floristic composition are poorly understood. The dominant socio-linguistic groups of the area are Pashtoon tribes, having a long history of medicinal plants utilization as a part of their indigenous primary health care system. The present study was carried out to describe the plant species diversity of Shinghar and to the inventory of some important wild medicinal, edible and endemic plants of the region. A total of 102 species belonging to 42 families and 88 genera were recorded. Herbs comprised $62 \%$ of documented plants, followed by shrubs (26\%) and trees (14\%). Medicinal plants of the area are being used in the treatment of many ailments like joint pains, stomach problems, skin allergies, and inflammation. Edible plants were $14 \%$ of the total recorded plants. The documented plants were also used for other use-categories than medicinal and edible purposes, including fodder, fencing, and ornamental. In addition, some of the medicinal plants were considered poisonous but used for medicine. The area's elevation ranged from 1,700 to 3,400 meters above sea level. The dominating tree was Pinus gerardiana, and the area is also known as the Chilghoza Forest. Asteraceae was the dominating family in the area with 14 species, followed by Lamiaceae ( 7 species), Poaceae (6 species), Solanaceae, Leguminosae, Fabaceae, and Apocynaceae with 5 species each. The results revealed the importance of the area's endemic and endangered plants that must be conserved. Moreover, the present study highlighted species diversity not earlier described from high altitudes.
\end{abstract}

Keywords: Floristic composition, folk uses, pinus forest, Shinghar, species diversity

\section{INTRODUCTION}

Plants play a key role in our daily life in different ways. Thousands of people have used plant resources since ancient times, such as food, medicine, daily households, live stocks, and many other ways (Cunningham 2001). Indigenous knowledge and traditional primary health care systems are predominantly common in communities throughout Asia. In addition, plant utilization by communities as medicines and religious and cultural rituals play a significant socioeconomic role (Niroula and Singh 2015; Zhu et al. 2016). Other than the rural areas, plantbased drugs are also used in urban cities. Plant-based drugs' use increases due to their afflictive role, being less expensive and having fewer side effects. Many researchers reported the different plant uses as essential oils, antioxidants, anti-inflammatory, and antidiabetic (Ahmed et al. 2020; Mustafa and Verpoorte 2007; Ntie-Kang et al. 2016).

Plants' primary and secondary metabolites are the major sources mostly used as phytomedicines and therapeutic that can be extracted from different plant parts like roots, stems, bark, leaves, flowers, seeds, and fruits, etc. (Nantongo et al. 2018; Pudziuvelyte et al. 2020; Trong Le et al. 2020). Plants are a natural source of different remedies, including cough, stomach disorders, headaches, joint pains, cardiovascular diseases, diuretics, and inflammation. They are even successfully used against cancer and diabetes.
Moreover, plants are diverse in nature and effective against more than one disease at a time (Khan et al. 2018; Moattar et al. 2015).

Plant use has been in the practice of human beings since earlier times. Approximately 80\% population of the world, mostly the rural regions of developing countries, continue using traditional resources in healthcare (Poonam and Singh 2009). In addition, the plants are used for food, shelter, culture, and many others. In recent years, various biophysical and socioeconomic factors have led to a depletion of natural resources across loss of ecosystem services, particularly regarding soil nutrients, water, biomass, and biodiversity. Earth is facing the threat of loss of biodiversity under excess use of plants by local communities, government and semi-government organizations, like the forest department, agriculture department, IUCN, and WWF need to work for biodiversity conservation as well as local communities work hand in hand with these organizations for saving biodiversity loos (Berkes and Turner 2006).

On the other hand, folk/traditional knowledge of the local communities decreased daily, possibly due to advanced medical techniques, allopathic medicines, and the stagnation of elder knowledge in the young generation (Pyke et al. 2001). Although ethnobotanical studies have been carried out in different parts of Pakistan, little work is documented from Northern Balochistan, Pakistan. The present study describes the floristic composition of 
Shinghar Northern Balochistan, Pakistan. It will elaborate on the species diversity as well as the inventory of these plants concerning their ethnobotanical uses. It will also indicate the medicinal systems of the various indigenous people (Pushtoon tribes) of Shinghar.

\section{MATERIALS AND METHODS}

\section{Study area}

Shinghar valley is a part of the Suleiman Mountain range of Northern Balochistan, Pakistan. The hill is wellwooded with edible pine forests. The elevation ranges from 1,500 to 3,000 meters above sea level. The annual rainfall is recorded at about 8 to 10 inches. The summer is recorded as hot and dry. Although the dominant language is PUSHTO verbal by more than $90 \%$ of the inhabitants, District Sherani has not yet developed, and people spend their life beneath the shadow of ancient cultures. Many of the population rely on healing plants rather than modern medicines.

\section{Data collection}

The study was conducted in communities of four villages, i.e. (i) Shinghar, (ii) Hassanzi, (iii) Omza, and (iv) Khankhai, between 2017 and 2018. Major tribes in the study area were Khankhai, Omza, Hassanzi, Harifal, Shana, and Abrahim Khail. Data were collected from 100 informants (male and female) through semi-structured interviews with the households and healers who served as key informants. In addition, we carried out community walks and plant collections. The informants were asked about age, education, occupation, and the medicinal plants, including the name of the plant, which part of the plant is used, which remedy is chosen, which disease is treated, how the plant is collected, and in which season/time, collected personally or purchased, how they store/preserve the collected plant part. Ethnobotanical uses are denoted by a numerical code as follows: (i) food, (ii) fodder, (iii) forage, (iv) medicinal, (v) ornamental, (vii) chemical, (vii) timber and other usages of wood, and (viii) fibers.

\section{Voucher specimens}

All the documented plants were collected through community walk with local communities and were examined to determine the botanical family and species name. The plants were preserved and identified with the help of a taxonomist. The plant specimens were submitted to the Botanical Garden Herbarium, the University of Balochistan Quetta, for future recodes.

\section{Data analysis}

Data were tabulated to analyze the total number of medicinal plants. Each plant is listed according to its family. Plants were also arranged according to their uses reported by the informants. The collected data were analyzed into two objectives, i.e. (i) The inventory listed the records of plants in the area and their relevant data. The use-value (UV) is also calculated to estimate the relative importance (RI) based on the number of plant use reported and the number of informants, (ii) Floristic compositions were calculated by (Whittaker 1972). Species diversity was calculated by (Nei and Li 1979) by using the formula Simpson index $D=-\Sigma_{i} p_{i}{ }^{2}$ and Shannon index $H=-\Sigma_{i} p_{i} \ln$ $p_{i}$.

\section{RESULTS AND DISCUSSION}

Plant floristic composition and diversity represented the variation along the altitudinal gradient. A total of 102 plant species belonging to 42 families were recorded at 1,700 to 3,400 meters above sea level (Table 1). The highest record was the Asteraceae family with 14 species, followed by Lamiaceae (7 species), Poaceae (6 species), Solanaceae, Leguminosae, Fabaceae, and Apocynaceae with 5 species each. The recorded numbers of Rosaceae were 4 species, including an economically important tree, Prunus dulcis. The record showed Chenopodiaceae, Convolvulaceae, Rhamnaceae, and Zygophyllaceae with 3 species each. The recorded numbers of Anacardia-ceae, Boraginaceae, Caryophyllaceae, Ephedraceae, Euphorbiaceae, Malvaceae, Oleaceae, Pinaceae, and Salicaceae were 2 species each. The economically important tree species included Pinus gerardiana (Chilghoza tree; Pinaceae) and Olea ferruginea (Zaitoon; Oleaceae).

All other families with 1 species included Amaryllidaceae, Apiaceae, Asparagaceae, Berberidaceae, Brassicaceae, Buxaceae, Campanulaceae, Gentianaceae, Menispermaceae, Moraceae, Morinaceae, Myrtaceae, Nitrariaceae, Papaveraceae, Plantaginaceae, Plumbaginaceae, Polygonaceae, Rubiaceae, Sapindaceae, Tamaricaeae, and Thymelaeaceae.

Table 2. Species richness based on Simpson's Index of Diversity along the altitudinal gradient

\begin{tabular}{ccccc}
\hline Elevation & No. of individuals & F & RF & D \\
\hline Low & 34 & 306 & 0.24 & 0.12 \\
Mid & 47 & 423 & 0.33 & 0.22 \\
High & 62 & 558 & 0.43 & 0.38 \\
Total & 143 & 1287 & 1 & 0.72 \\
\hline
\end{tabular}

Note: F: Frequency, RF: Relative Frequency, D: Simpson's Index of Diversity

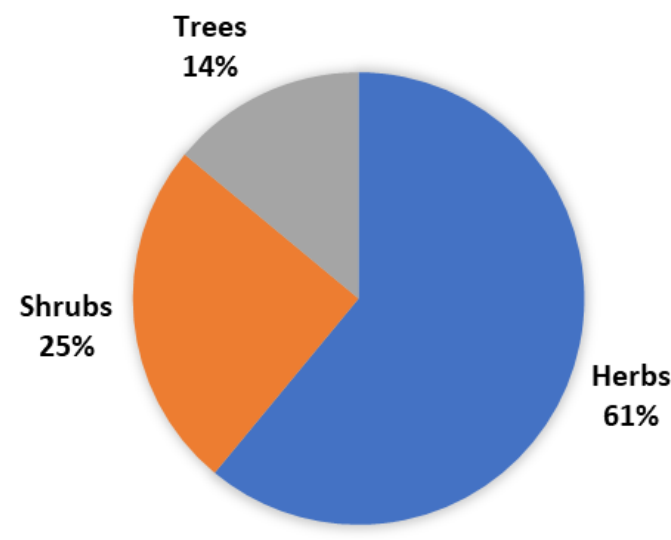

Figure 1. Distribution of life-form 
Table 1. List of plants reported from the study area

\begin{tabular}{|c|c|c|c|c|c|c|c|c|c|c|}
\hline Botanical name & Family & Local name & $\begin{array}{l}\text { Parts } \\
\text { used }\end{array}$ & Fodder & Medicines & $\begin{array}{c}\begin{array}{c}\text { Vegetables/ } \\
\text { fruits }\end{array} \\
\end{array}$ & Livestock & Fuel & Others & $\begin{array}{l}\text { Earlier } \\
\text { reports }\end{array}$ \\
\hline Allium griffithianum Boiss. & Amaryllidaceae & Pyaz & WP & $*$ & $*$ & $*$ & & & & Yes \\
\hline Pistacia atlantica Desf. & Anacardiaceae & Shiney & $\mathrm{F}, \mathrm{L}$ & & $*$ & $*$ & & $*$ & & Yes \\
\hline Pistacia khinjuk Stocks & Anacardiaceae & Shinay & $\mathrm{F}, \mathrm{L}$ & & * & * & & $*$ & & Yes \\
\hline Foeniculum vulgare Mill. & Apiaceae & Kaga & WP & & $*$ & $*$ & & & & Yes \\
\hline Calotropis procera (Aiton) Dryand & Apocynaceae & Spelmi & WP & * & $*$ & & & & & Yes \\
\hline Caralluma tuberculata N.E.Br. & Apocynaceae & Unknown & $\mathrm{F}$ & & $*$ & $*$ & & & & Yes \\
\hline Periploca aphylla Decne. & Apocynaceae & Bara & WP & $*$ & $*$ & $*$ & & * & & Yes \\
\hline Nerium oleander $\mathrm{L}$. & Apocynaceae & Gandeeri & WP & & & & & & $*$ & Yes \\
\hline Rhazya stricta Decne. & Apocynaceae & Ghanderay & WP & & $*$ & $*$ & & $*$ & & Yes \\
\hline Asparagus capitatus Baker & Asparagaceae & Unknown & WP & $*$ & & & & & & No \\
\hline Ajania fruticulosa (Ledeb.) Poljakov & Asteraceae & Unknown & NUR & & & & & & & Yes \\
\hline Artemisia stenocephala Krasch. Ex Poljakov & Asteraceae & Tharkha & WP & & * & & & & & Yes \\
\hline Cirsium arvense (L.) Scop. & Asteraceae & Spinboti azghi & WP & & * & & & & & Yes \\
\hline Cousinia prolifera Jaub. \& Spach & Asteraceae & Da vezo azghi & WP & * & & & & & & Yes \\
\hline Launaea acanthodes (Boiss.) Kuntze & Asteraceae & Aghzai/Zoz & WP & $*$ & & & & & & Yes \\
\hline Launaea acaulis (Roxb.) Babc. ex Kerr & Asteraceae & Unknown & NUR & & & & & & & No \\
\hline Lactuca dissecta D.Don & Asteraceae & Unknown & NUR & & & & & & & Yes \\
\hline Lactuca serriola $\mathrm{L}$. & Asteraceae & Markwraka & WP & $*$ & $*$ & $*$ & * & & & Yes \\
\hline Phagnalon niveum Edgew. & Asteraceae & Unknown & NUR & & & & & & & Yes \\
\hline Pulicaria undulata (L.) C.A.Mey & Asteraceae & Unknown & NUR & & & & & & & Yes \\
\hline Tagetes minuta $L$. & Asteraceae & Unknown & & & & & & & * & Yes \\
\hline Tragopogon gracilis D.Don & Asteraceae & Gwaryshlgi & WP & $*$ & & & & & & Yes \\
\hline Xanthium strumarium $\mathrm{L}$. & Asteraceae & Genjali & $\mathrm{F}$ & $*$ & * & & & & & Yes \\
\hline Verbesina encelioides (Cav.) Benth. \& Hook.f. ex A.Gray & Asteraceae & Unknown & NUR & & & & & & & Yes \\
\hline Berberis calliobotrys Bien. ex Koehne & Berberidaceae & Unknown & $\mathrm{F}$ & $*$ & $*$ & & & & & Yes \\
\hline Lappula barbata (M.Bieb.) Gürke & Boraginaceae & Unknown & NUR & & & & & & & Yes \\
\hline Onosma limitaneum I.M. Johnst. & Boraginaceae & Unknown & NUR & & & & & & & Yes \\
\hline Sisymbrium irio L. & Brassicaceae & Jangli sarso & S & * & * & & & & & Yes \\
\hline Buxus papillosa C.K.Schneid. & Buxaceae & shamshad & NUR & & & & & & & Yes \\
\hline Campanula sulaimanii Nasir. & Campanulaceae & Unknown & NUR & & & & & & & Yes \\
\hline Dianthus crinitus $\mathrm{Sm}$. & Caryophyllaceae & Unknown & NUR & & & & & & & Yes \\
\hline Saponaria subrosularis Rech. f. & Caryophyllaceae & Unknown & NUR & & & & & & & No \\
\hline Chenopodium album $\mathrm{L}$. & Chenopodiaceae & Sarma & $\mathrm{L}$ & $*$ & $*$ & $*$ & & & & Yes \\
\hline Haloxylon griffithii (Moq.) Boiss & Chenopodiaceae & Showri & WP & & & & & $*$ & * & Yes \\
\hline Salsola kali subsp. tragus (L.) Čelak. & Chenopodiaceae & Calbi & WP & $*$ & & & & & & Yes \\
\hline Convolvulus arvensis L. & Convolvulaceae & Unknown & WP & $*$ & * & & & & & Yes \\
\hline Convolvulus spinosus Burm. f. & Convolvulaceae & Unknown & WP & $*$ & & & & & & Yes \\
\hline Evolvulus alsinoides (L.) L. & Convolvulaceae & Shankh Pushpi & WP & & & & & & & No \\
\hline Ephedra intermedia Schrenk \& C.A.Mey. & Ephedraceae & Oman & WP & & * & & & $*$ & & Yes \\
\hline
\end{tabular}




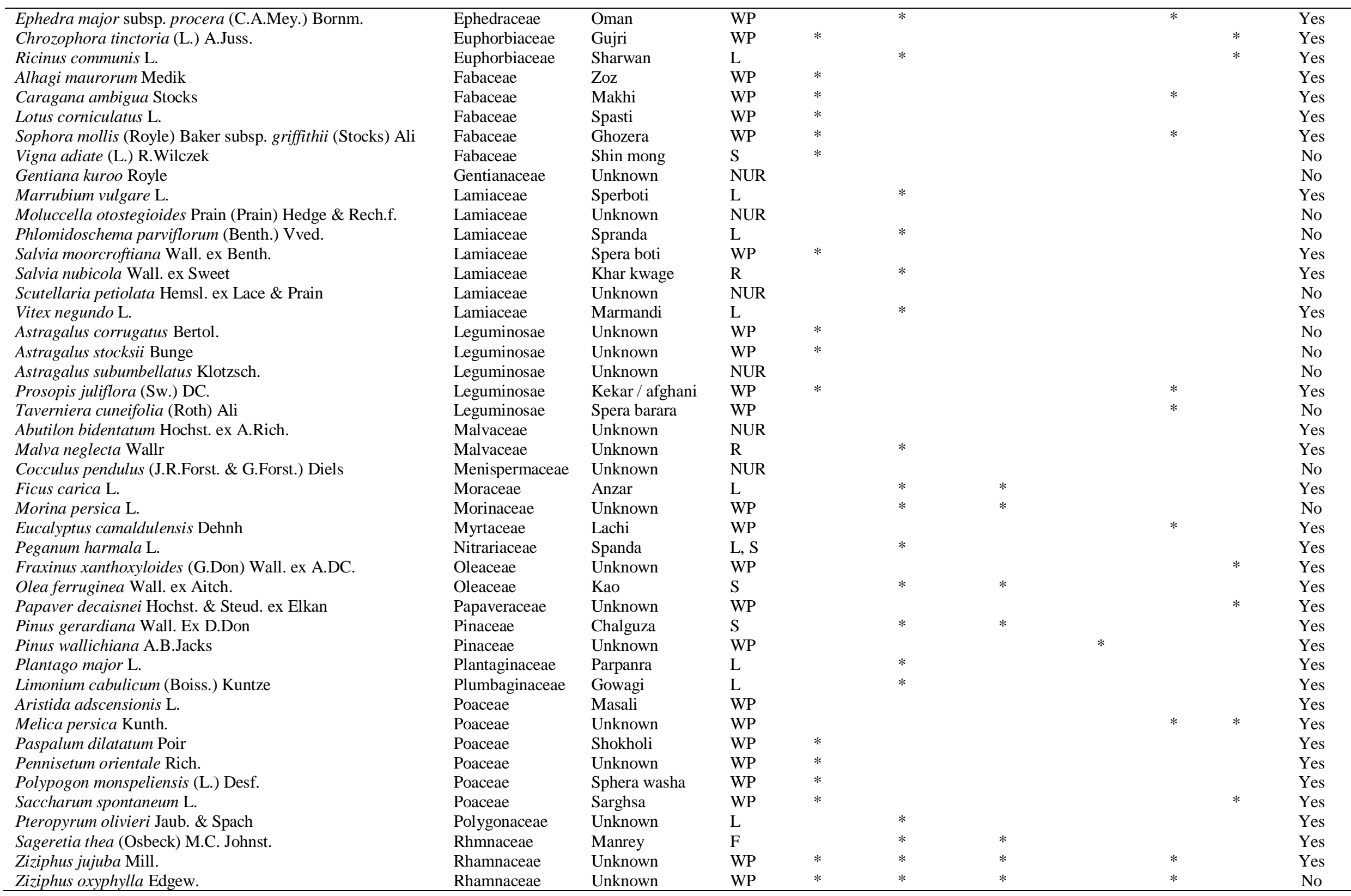




\begin{tabular}{|c|c|c|c|c|c|c|c|c|c|c|}
\hline Prunus brahuica (Boiss.) Aitch. \& Hemsl. & Rosaceae & Zargha/Kundzari & F & & * & $*$ & & * & & Yes \\
\hline Prunus dulcis (Mill.) D.A.Webb & Rosaceae & Badam & $\mathrm{F}$ & & $*$ & * & & * & & Yes \\
\hline Prunus rechingeri (Browicz) R.R.Stewart & Rosaceae & Unknown & $\mathrm{F}$ & & $*$ & $*$ & & $*$ & & No \\
\hline Cotoneaster persicus Pojark. & Rosaceae & Sharave & $\mathrm{L}$ & & $*$ & & & & & No \\
\hline Plocama macrantha (Blatt. \& Hallb.) M.Backlund \& Thulin. & Rubiaceae & Kharbat & WP & $*$ & & & & & & Yes \\
\hline Dodonaea viscosa (L.) Jacq & Sapindaceae & Unknown & $\mathrm{L}$ & & $*$ & & & & & Yes \\
\hline Populus euphratica Oliv. & Salicaceae & Spana & ST & & $*$ & & & $*$ & * & Yes \\
\hline Salix acmophylla Boiss. & Salicaceae & Wana & WP & & $*$ & & & * & & Yes \\
\hline Datura innoxia Mill. & Solanaceae & Badboya Boti & $\mathrm{L}$ & & $*$ & & & & & Yes \\
\hline Hyoscyamus insanus Stocks & Solanaceae & Unknown & WP & & $*$ & & & & & Yes \\
\hline Solanum rostratum Dunal. & Solanaceae & Marhaghonay & WP & $*$ & $*$ & & & & & Yes \\
\hline Solanum surattense Burm.f & Solanaceae & Marhaghonai & WP & * & $*$ & & & & & Yes \\
\hline Withania coagulans (Stocks) Dunal & Solanaceae & Khamazura & $\mathrm{S}$ & & $*$ & & & & & Yes \\
\hline Tamarix aphylla (L.) H.Karst & Tamaricaeae & Ghaz & WP & $*$ & & & $*$ & * & $*$ & Yes \\
\hline Daphne mucronata Royle. & Thymelaeaceae & Laghoni & WP & & $*$ & & & & & Yes \\
\hline Fagonia bruguieri DC & Zygophyllaceae & Azghi & WP & & $*$ & & & & & Yes \\
\hline Tribulus pentandrus Forssk & Zygophyllaceae & Kroundki/wazi & $\mathrm{S}$ & $*$ & * & & & & & Yes \\
\hline Tribulus terrestris $\mathrm{L}$. & Zygophyllaceae & Kroundki/wazi & $S$ & $*$ & $*$ & & & & & Yes \\
\hline
\end{tabular}

Note: S: Seeds, WP: Whole Plant, F: Flowers, ST: Stem, L: Leaf, R: Root, NUR: No use report 
The species reported were classified based on their life form (Figure 1). The herbs were dominant in the area, represented by 62 species $(61 \%)$, followed by shrubs $(26$ species; $25 \%$ ) and tree species (14 species; 14\%).

\section{Plant parts used and modes of preparation}

Different plant parts used for medicinal purposes are listed in Table 1. The most dominant plant part was whole plants (51), followed by leaves (15), flowers (10), and seeds (8), whereas a few roots and stems were also reported. The most common method of preparing the medicinal plants was decoction, followed by crushing the plant material for making a poultice $(23.1 \%)$, broth $(4.1 \%)$, and soaking in alcohol $(2.5 \%)$. Some species were mixed with other natural materials, such as the preparation of tonics made of medicinal plants combined with brown sugar, grains, chicken, pork, and other materials.

\section{Plant uses}

The documented plants included medicinal as well as some other plants. The medical plants recorded $36 \%$ of the reported plants, followed by fodder (26\%), edible/food $(14 \%)$, and fuel $(13 \%)$. Livestock was recorded at $4 \%$, and the remaining uses $(9 \%)$ included construction, fencing, cloth dye, ornamental, and yokes. The results showed that the community used medicinal plants in different ways. Some uses were unique to the region and not reported earlier from any region of Balochistan. In contrast, other uses were common to other communities of neighboring villages in other parts of Balochistan, Pakistan.

\section{Plants used as a food}

Some fruits were edible and used by the community of Shinghar listed in Table 1. They included Pinus gerardiana, which is very important in the area. Fruit is very popular and taken as dry fruit. Fruits/berries of Pistacia atlantica, P. khinjuk, and Berberis calliobotrys are important medicinal plants used as dry fruits by local communities. Foeniculum vulgare (Apiaceae) seeds are flavoring agents used in baking different things, as well as cooking meat and fish to improve flavor. Allium griffithianum was used as a vegetable in cooking different types of food. Caralluma tuberculate, also known as Pamanky in Pashto, was cooked and eaten as a vegetable. Artemisia stenocephala was used to give a taste to milk. The leaves of Chenopodium album were boiled in water and eaten as a vegetable. The fruit of Ficus carica is used as dry fruit and also consumed as fresh fruit. The fruit of Olea ferruginea was a very healthy and valuable source of food in the area. The leaves of Morina persica were used to make tea.

\section{Plants used as traditional medicines}

A total of $36 \%$ of reported plants were used in traditional medicines (Table 1). Allium griffithianum was used as food as well as medicinal importance, used to treat jaundice and flatulent dyspepsia. The fruits of Pistacia atlantica and $P$. khinjuk were edible sources for the community of Shinghar; the medicinally important fruit was used to treat stomach diseases, renal disorders, wounds, and coughs. Foeniculum vulgare (Apiaceae), commonly known as fennel, was a well-known and important medicinal and aromatic plant widely used as a carminative, digestive, galactagogue, diuretic, and treating respiratory and gastrointestinal disorders. Caralluma tuberculate was also used as a folk medicine to treat diabetes and rheumatism. Periploca aphylla is used to treat tumors, and swellings latex of the plant is applied on infected areas and joints with inflammation. The plant is also known as "Bata" or "Barara." The plant is also used to treat cough and flu. Rhazya stricta is also known as a Blood purifier plant used to treat diabetes. The powder of Cirsium arvense (Syn Carduus arvensis) was used for toothache. Launaea acanthodes is a very important plant, and many studies are found on its essential oil extraction. L. acaulis was used as a diuretic and stomachic. Berberis calliobotrys are the local communities of Shingar that also use a very important medicinal plant, the roots of Berberis. The seed powder of Sisymbrium irio was used for treating asthma and produced a cooling effect to treat stomach disorders, constipation, and abdominal pain. The whole plant of Evolvulus alsinoides was used to treat fever and neuro disorders. Ephedra intermedia was used to treat asthma, and E. major subsp. procera juice was used for treating asthma. The powder of Ricinus communis was used for stomach pain. The decoction of leaves of Marrubium vulgare was used for gastric gas. The ground leaves powder of Phlomidoschema parviflorum was used for wound recovery. The decoctions of roots of Salvia nubicola were used for cough and cold. The leaves of Vitex negundo were used for gastric gas and pain. Ficus carica was used for blood purification. The leaves of Peganum harmala were mixed with oil and boiled for a few minutes, and then filtered juice was used for muscle and joint pains, while seeds were used for gastric problems. The leaves of Plantago major were used for tonic and antiseptics. The juice of ground leaves of Limonium cabulicum was used for stomach problems. The seeds of Withania coagulans were put into the water for a night and, early in the morning, drank it, which was useful against malaria. The power of Fagonia bruguieri was used for asthma diseases. Tribulus terristrus was used for kidney disorders.

\section{Plants used for fuel}

Plant diversity was disturbed due to the excessive use of plants as fuel (Table 1). It mostly included Populus euphratica, Pistacia atlantica, P. khinjuk, Berberis calliobotrys, Buxus papillosa, Caragana ambigua, Sophora mollis subsp. griffithii, Prosopis juliflora, Taverniera cuneifolia, Eucalyptus camaldulensis, Fraxinus xanthoxyloides, Olea ferruginea, Pinus gerardiana, Pinus wallichiana, Ziziphus jujube, Ziziphus oxyphylla, Prunus brahuica, Prunus dulcis, Prunus rechingeri, Populus euphratica, Salix acmophylla, Tamarix aphylla, Ephedra intermedia, and E. major subsp. procera.

\section{Plants used as fodder}

One of the key roles of the plants was their use as fodder (Table 1). Reported fodder plants were Alhagi maurorum, Buxus papillosa, Cousinia prolifera, Caragana 
ambigua, Lotus corniculatus, Vigna adiate, Salvia moorcroftiana, Prosopis juliflora, Aristida adscensionis, Paspalum dilatatum, Polypogon monspeliensis, Saccharum spontaneum, Prunus dulcis, Solanum rostratum, S. surattense, Tragopogon gracilis, Tribulus pentandrus. Whole plants were used as fodder.

\section{Plants to treat animal bites and mosquito repellent}

Calotropis procera leaves were used to treat Scorpion bites (Table 1), while the leaves of Daphne mucronata were used as a mosquito repellent. Verbesina encelioides was used as an insecticide.

\section{Plants used to treat skin diseases}

The leaves of Daphne mucronata, Periploca aphylla, Buxus papillosa, and Ziziphus jujuba were used to treat skin diseases/infections. In addition, the latex of Calotropis procera was used to treat skin diseases known as Sponi in the local language (Table 1).

\section{Other uses}

Nerium oleander, Tagetes minuta, and Papaver decaisne were used for ornamental purposes (Table 1). Tamarix aphylla and Chrozophora tinctoria were used to dye the clothes. Caragana ambigua was used for fencing, while Fraxinus xanthoxyloides was used to make yokes.

\section{Species diversity}

A total of 102 plants reported from the study area showed species diversity along the altitudinal gradient. Rich species diversity was obtained at high altitudes followed by middle elevation, and low diversity was obtained at low elevation zone. Therefore, the species richness of the Shinghar mountain range was assessed along the altitudinal gradient shown in Table 2. Simpson's Index of Diversity was higher at high elevations, followed by middle and low elevations (Table 2).

\section{Discussion \\ Ethnobotanical inventory in the folk community of Shinghar}

The 102 documented plant species belong to 42 families, and the highest record was the Asteraceae family, with 14 species. Medicinal plants of the Asteraceae family have previously been shown to be commonly used by rural communities in Pakistan Balochistan (Durrani and Hussain 2005; Sarangzai et al. 2013; Tareen et al. 2010). Asteraceae is one of the advanced families of seed plants worldwide and is easily available in local communities to be used as a vegetable, fruit, seasoning, and starch (Sui et al. 2011). Ajania fruticulosa was recorded from the informants of Shinghar earlier, but the essential oils of A. fruticulosa were isolated by (Liang et al. 2016) and (Abbas et al. 2020). Artemisia stenocephala was used to taste milk; the earlier study was reported from Northern Areas of Pakistan (Ashraf et al. 2010). The powder of Cirsium arvense (Syn Carduus arvensis) was used for toothache; in earlier reports, it was found to improve digestion and used for child worms (Tufail et al. 2020; Yasine et al. 2013). The whole Cousinia prolifera plant was used as fodder; in an earlier study, the plant was reported for treating diabetes mellitus II in South-West Pakistan (Zain-ul-Abidin et al. 2018). Launaea acanthodes is a very important plant; many reports were found on its essential oil extraction and medicinal uses around the world (Mood 2008; Taherian et al. 2018), while L. acaulis was used as a diuretic, stomachic, and blood purifier (Jain et al. 2010). Lactuca serriola is a medicinally important plant; earlier reports were from different ecological zones of Pakistan, the Wana District of South Waziristan, and Balochistan. In the present study, L. serriola was reported for livestock. Lactuca dissecta was reported from the Himalaya and Hindukush ranges of Pakistan Dir, Timergara KPK, Pakistan (Shuaib et al. 2019). Phagnalon niveum was reported from the Biodiversity of Shinghar area, but the use report was not recorded from the communities of Shinghar. In earlier reports from Balochistan, the plant was used as an anticancer, also reported from Nowshera KPK, Pakistan (Ali et al. 2019). Pulicaria undulata (Syn. Pulicaria crispa) was earlier reported from Indus plans Pakistan (Khan and Qaiser 2006). No use report was recorded from the communities of Shinghar. Essential oils of $P$. undulata are used for antimicrobial activity (Mohamed et al. 2020). No use report of Tagetes minuta was recorded from the communities of Shinghar; leaves paste typically used for wound healing, has anti-inflammatory and bronchodilatory (Abbasi et al. 2010), and is also used as a bio-herbicide for weed control (Sadia et al. 2013). Tragopogon gracilis was reported as fodder from the Shingar. In earlier records, $T$. gracilis was reported from Dir Upper, Khyber Pakhtunkhwa, Pakistan (Awasthi et al. 2003). Xanthium strumarium is a noxious weed; earlier reports were found from the Takht-e-Suleman range FR D.I. Khan, Pakistan (Samreen et al. 2016). As a traditional herbal medicine, $X$. strumarium has been extensively applied to treat many diseases, such as rhinitis, nasal sinusitis, headache, gastric ulcer, urticaria, rheumatism bacterial, fungal infections, and arthritis (Fan et al. 2019). Verbesina encelioides is regarded as a notorious weed and an ornamental garden; the plant has been found to have various uses in folk medicine in different parts of the world. It possesses analgesic, emetic, febrifuge, and insecticidal properties (Jain et al. 2008). The Lamiaceae family comprises aromatic plants, the second dominating family used by Shinghar community. The family includes the taxa used for a stomach disorder. It was also reported from Balochistan, Pakistan, that the decoction of leaves of Marrubium vulgare and Vitex negundo were used for gastric gas (Bibi et al. 2014). Five species of Ephedra were found in Balochistan (Saeed et al. 2015). Medicinal plants have been used by local communities of Balochistan, Pakistan, for centuries (Adnan et al. 2014; Ahmad and Husain 2008; Ahmed 2020). The E. intermedia was used as a source of fuelwood and ephedrine nasal drops. It is mixed with tobacco for the preparation of good quality, and it was also used for the treatment of asthma. The juice of Ephedra major subsp. procera was used for treating asthma (Bibi et al. 2014). Allium griffithianum was used as food and had medicinal importance, used to treat jaundice and flatulent dyspepsia for people of any age, including children, as reported by (Amjad et al. 2020; Arshad et al. 2014; Jan et al. 2016). The fruits of Pistacia 
atlantica and P. khinjuk were edible sources for the community of Shinghar and were medicinally used to treat stomach diseases, renal disorders, wounds, and coughs. Our findings agreed with earlier reports of Pistacia species (Bibi et al. 2014; Mahjoub et al. 2018; Sarangzai et al. 2013). Foeniculum vulgare aromatic plant has medicinal importance and is commonly known as fennel, and its commonly used for treating digestive problems. Seeds are also used to improve flavor in cooking meat etc. (Xiong et al. 2020). Phytochemicals of $F$. vulgare include different Phenols, phenolic glycosides, and volatile aroma , transanethole, estragole, and fenchone (Andrade-Cetto 2009). Earlier, its many in vitro and in vivo uses are reported as antifungal, antibacterial, antioxidant, antithrombotic, and hepatoprotective (Rather et al. 2016; Samreen et al. 2016). The fruit and latex of Calotropis procera have medicinal properties; leaves were used to treat Scorpion bites, while latex was used to cure skin diseases known as Sponi in the local language. The root powder of $C$. procera mixed with goat milk was used in epilepsy, as earlier reported by (Bhatti et al. 1998; Panhwar and Abro 2007; Parihar and Balekar 2016). Caralluma tuberculate, also known as Pamanky in Pashto, was cooked and eaten as a vegetable. It is used to treat diabetes and rheumatism by folk communities (Rauf et al. 2013; Bibi et al. 2014). Periploca aphylla is earlier reported for treating skin diseases, ulcers, and constipation (Iqbal et al. 2012; Samreen et al. 2016). In many cases, Nerium oleander is a potentially lethal plant and reported poisoning, used for ornamental purposes. The leaves and flowers have been reported to have medicinal properties (Farooqui and Tyagi 2018). Earlier reported uses were cardiotonic, diaphoretic, diuretic, anticancer, antibacterial, and anticancer. Flowers, leaves, leaf juice or latex, bark, and roots have been used against corns, warts, cancerous ulcers, carcinoma, ulcerating or hard tumors (Begum et al. 1999).

Rhazya stricta is also known as a blood purifier plant and is used to treat diabetes. Some uses against the allergy were also reported in the current study. Earlier reports from different areas of Balochistan used different decoctions for various unrelated illnesses like diabetes mellitus, fever, sore throat, inflammatory conditions, and helminthiasis (Panhwar and Abro 2007; Bibi et al. 2014; Samreen et al. 2016). Asparagus capitatus is described as food and medicine for various ailments. The earlier report from Balochistan was (Attaullah and Muhammad 2016). Berberis calliobotrys is a very important medicinal plant. The berries have been reported to have medicinal importance and are consumed as dry fruits. The plant root is also used by the local communities of Shingar (Saeed et al. 2016). Also, earlier reports were for anti-inflammatory, analgesic, and antipyretic activities (Alamgeer et al. 2016). No use report of Lappula barbata is from the communities of Shingar, but earlier reports elaborated on its importance in antiviral and anti-inflammatory activities (Soliman et al. 2016). Also, no use report of Onosma limitaneum is from the interviews of communities during the survey of Shingar, but the plant has been identified to have great medicinal importance (Sarangzai et al. 2013). Different species of Onosma are reported to have anti-inflammatory, anticancer, and anti-nociceptive activities (Tosun et al. 2008). The seed powder of Sisymbrium irio was used for treating asthma and producing a cooling effect to treat stomach disorders, constipation, and abdominal pain. Earlier studies reported the plant had been used in folk medicine to treat febrifuge, asthma, and fevers (AlQudah and Abu Zarga 2010; Bibi et al. 2014; Samreen et al. 2016). Buxus papillosa was traditionally used for food, shelter, fodder, health care, and other cultural purposes. Earlier studies reported the plant had been extensively utilized in the indigenous medicinal system for treating common ailments, including skin infections, malaria, and rheumatism (Asif et al. 1992; Saleem et al. 2019). Campanula sulaimanii was used as fodder in the Shingar. The plant is endemic to the region; Our findings agree with an earlier report (Badshah et al. 2016). The leaves of Peganum harmala are mixed with oil and boiled for a few minutes, and then filtered juice was used for muscle, and joint pain, while seeds were used for gastric problems. Fagonia bruguieri was used for asthma diseases, while Tribulu terristrus was used for kidney-related issues (Bibi et al. 2014; Ahmed et al. 2020).

\section{Species richness and conservation}

The species diversity of edible, medicinal, and other ethnobotanical plants reported from Shinghar showed a different pattern than earlier reports from different zones of Balochistan. Few plants were reported in species diversity, but no use was recorded from the Shinghar communities of four studied villages. Whereas some medicinal plants used were reported by Shinghar communities but not found in our field surveys. The uses of medicinal plants and remedies we have documented indicate the vast knowledge of the old age community, which may serve to supplement the whole medicinal system in the area so that they should be protected and maintained.

In conclusion, medicinal plants used by the Pashtoon tribes in Shinghar Balochistan are very diverse. One hundred and twenty-one species belonging to 54 families were documented for treating various ailments based on ethnobotanical appraisal in four villages of the study area. Few ethnobotanical records were documented for the first time. According to reported information by local communities, the leaves and whole plants used reports were higher. However, this indigenous knowledge of the communities must be conserved urgently as, with time, this knowledge is depleting daily. That is best accomplished by documenting the unique knowledge and practice of ethnic groups concerning medicinal plants.

\section{ACKNOWLEDGEMENTS}

We are grateful to the local people in study areas who have provided valuable information about the medicinal plants and shared their prestigious knowledge for improving ethnobotanical uses. Also, we would like to thank Nazer Khan for his help in plant identification. 


\section{REFERENCES}

Abbas Z, Khan SM, Alam J, Abideen Z, Ullah Z. 2020. Plant communities and anthropo-natural threats in the Shigar valley (Central Karakorum) Baltistan-Pakistan. Pak J Bot 52: 987-994. DOI: 10.30848/PJB2020-3(5).

Abbasi AM, Khan MA, Ahmad M, Qureshi R, Arshad M, Jahan S, Zafar M, Sultana S. 2010. Ethnobotanical study of wound healing herbs among the tribal communities in Northern Himalaya Ranges District Abbottabad, Pakistan. Pak J Bot 42: 3747-3753.

Adnan M, Ullah I, Tariq A, Murad W, Azizullah A, Khan AL, Ali N. 2014. Ethnomedicine use in the war affected region of northwest Pakistan. J Ethnobiol Ethnomed 10: 16. DOI: 10.1186/1746-4269-1016

Ahmad SS, Husain SZ. 2008. Ethno medicinal survey of plants from salt range (Kallar Kahar) of Pakistan. Pak J Bot 40: 1005-1011.

Ahmed A, Hameed A, Saeed S. 2020a. Biochemical profile and bioactive potential of thirteen wild folk medicinal plants from Balochistan, Pakistan. PloS ONE 15: e0231612. DOI 10.1371/journal.pone.0231612.

Ahmed A, Hameed A, Saeed S. 2020b. Ecological distribution, morphological and molecular characterization of Zygophyllaceae from diverse ecological zones of Balochistan, Pakistan. Appl Ecol Environ Res 18: 2445-2462. DOI: 10.15666/aeer/1802 24452462.

Alamgeer NH, Rasool S, Raza SA, Ahmad T, Ahsan H, Mushtaq MN, Asif H, Khan Z, Noor N, Utra A. 2016. Anti-inflammatory, analgesic and antipyretic activities of the aqueous methanolic extract of Berberis calliobotrys in albino mice. Acta Pol Pharm 73: 717-723

Ali S, Shah SZ, Khan MS, Khan WM, Khan Z, Hassan N, Zeb U. 2019. Floristic list, ecological features and biological spectrum of district Nowshera, Khyber Pakhtunkhwa, Pakistan. Acta Ecol Sin 39: 133141. DOI: 10.1016/j.chnaes.2018.08.007.

Al-Qudah MA, Zarga MHA. 2010. Chemical constituents of Sisymbrium irio L. from Jordan. Nat Prod Res 24: 448-456. DOI: 10.1080/14786410903388025.

Amjad MS, Zahoor U, Bussmann RW, Altaf M, Gardazi SMH, Abbasi AM. 2020. Ethnobotanical survey of the medicinal flora of Harighal, Azad Jammu \& Kashmir, Pakistan. J Ethnobiol Ethnomed 16: 1-28. DOI: 10.1186/s13002-020-00417-w.

Andrade-Cetto A. 2009. Ethnobotanical study of the medicinal plants from Tlanchinol, Hidalgo, México. J Ethnopharmacol 122: 163-171. DOI: 10.1016/j.jep.2008.12.008. DOI: 10.1016/j.jep.2008.12.008.

Arshad M, Ahmad M, Ahmed E, Saboor A, Abbas A, Sadiq S. 2014. An ethnobiological study in Kala Chitta hills of Pothwar region, Pakistan: Multinomial logit specification. J Ethnobiol Ethnomed 10: 1-17. DOI: 10.1186/1746-4269-10-13

Ashraf M, Hayat MQ, Mumtaz AS. 2010. A study on elemental contents of medicinally important species of Artemisia L. (Asteraceae) found in Pakistan. J Med Plants Res 4: 2256-2263.

Asif E, Ali SS, Nasir H, Jamal SA, Ata A, Farooq A, Choudhary MI, Sener B, Turkoz S. 1992. New steroidal alkaloids from the roots of Buxus papillosa. J NatProd 55: 1063-1066. DOI 10.1021/np50086a005

Attaullah KN, Muhammad Z. 2016. A check list of angiospermic plants of Sheikh Buddin National Park, District Dera Ismail Khan, Khyber Pakhtunkhwa, Pakistan. S Asian J Life Sci 4: 18-24. DOI: 10.14737/journal.sajls/2016/4.1.18.24.

Awasthi A, Uniyal SK, Rawat GS, Sathyakumar S. 2003. Food plants and feeding habits of Himalayan ungulates. Curr Sci 85: 719-723.

Badshah L, Hussain F, Sher Z. 2016. Floristic inventory, ecological characteristics and biological spectrum of plants of Parachinar, Kurram agency, Pakistan. Pak J Bot: 48: 1547-1558.

Begum S, Siddiqui BS, Sultana R, Zia A, Suria A. 1999. Bio-active cardenolides from the leaves of Nerium oleander. Phytochemistry 50: 435-438. DOI: 10.1016/S0031-9422(98)00523-8.

Bhatti G, Qureshi R, Shah S. 1998. Ethnobotany of Calotropis procera with special reference to the people of Nara Desert. Sci Sindh 5: 1322.

Bibi T, Ahmad M, Tareen RB, Tareen NM, Jabeen R, Rehman SU, Sultana S, Zafar M, Yaseen G. 2014. Ethnobotany of medicinal plants in district Mastung of Balochistan province-Pakistan. J Ethnopharmacol 157: 79-89. DOI: 10.1016/j.jep.2014.08.042.

Berkes, F., Turner, N. J. (2006). Knowledge, learning and the evolution of conservation practice for social-ecological system resilience. Human ecology, 34(4), 479-494.
Cunningham AB. 2001. Applied Ethnobotany: People, Wild Plant Use and Conservation. Routledge.

Din ZUA, Khan R, Ahmad M, Bhatti MZ, Zafar M, Saeed A, Khan N. 2018. Ethnobotanical survey of highly effective medicinal plants and phytotherapies to treat diabetes mellitus II in South-West Pakistan. Indian J Tradit Knowl 17(4):682-690

Durrani MJ, Hussain F. 2005. Ethnoecological profile of plants of Harboi rangeland, Kalat, Pakistan. Int J Bio Biotech 2: 15-22.

Fan W, Fan L, Peng C, Zhang Q, Wang L, Li L, Wang J, Zhang D, Peng W, Wu C. 2019. Traditional uses, botany, phytochemistry, pharmacology, pharmacokinetics and toxicology of Xanthium strumarium L.: A review. Molecules 24: 359. DOI: 10.3390/molecules24020359.

Farooqui S, Tyagi T. 2018. Nerium oleander: It's application in basic and applied science: A Review. Int J Pharm Pharm Sci 10: 1. DOI: 10.22159/ijpps.2018v10i3.22505

Iqbal J, Zaib S, Farooq U, Khan A, Bibi I, Suleman S. 2012. Antioxidant, antimicrobial, and free radical scavenging potential of aerial parts of Periploca aphylla and Ricinus communis. ISRN Pharmacol 2012(2): 563267. DOI: $10.5402 / 2012 / 563267$.

Jain DL, Baheti AM, Jain SR, Khandelwal KR. 2010. Use of medicinal plants among tribes in Satpuda region of Dhule and Jalgaon districts of Maharashtra-An ethnobotanical survey. Indian J Tradit Knowl 9: $152-157$

Jain S, Jain R, Singh R, Menghani E. 2008. Verbesina encelioides: Perspective and potentials of a noxious weed. Indian J Tradit Knowl 7: 511-513

Jan PS, Sadia B, Yousaf A, Naz A, Rehmat N, Tahira B, Sajjad N, Hameed S, Bazai ZA. 2016. Ethnobotanical study of flora of Gulistan, district Killa Abdullah, Balochistan, Pakistan. Pure Appl Biol 5: 361. DOI: 10.19045/bspab.2016.50047.

Khan AL, Hamayun M, Hussain J, Khan H, Gilani SA, Kikuchi A, Watanabe KN, Jung EH, Lee I. 2009. Assessment of allelopathic potential of selected medicinal plants of Pakistan. Afr J Biotechnol 8(6): 1024-1029.

Khan MA, Qaiser M. 2006. Halophytes of Pakistan: Characteristics, Distribution and Potential Economic Usages Sabkha Ecosystems. Springer. DOI: 10.1007/978-1-4020-5072-5 11.

Khan W, Khan SM, Ahmad H. 2018. Ethno-ecology, human health and plants of the Thandiani sub forest division. In: Abbottabad KP (eds). Pakistan Plant and Human Health. Volume 1. Springer. DOI: 10.1007/978-3-319-93997-1_13.

Liang JY, Guo SS, You CX, Zhang WJ, Wang CF, Geng ZF, Deng ZW, Dua SS, Zhang J. 2016. Chemical constituents and insecticidal activities of Ajania fruticulosa essential oil. Chem Biodivers 13: 1053-1057. DOI: $10.1002 / \mathrm{cbdv} .201500377$.

Mahjoub F, Rezayat KA, Yousefi M, Mohebbi M, Salari R. 2018. Pistacia atlantica Desf: A review of its traditional uses, phytochemicals and pharmacology. J Med Life 11: 180. DOI: 10.25122/jml-2017-0055.

Moattar FS, Sariri R, Giahi M, Yaghmaee P, Ghafoori H, Jamalzadeh L. 2015. Antioxidant and anti-proliferative activity of Calamintha officinalis extract on breast cancer cell line MCF-7. J Biol Sci 15: 194-198. DOI: 10.3923/jbs.2015.194.198.

Mohamed EAA, Muddathir AM, Osman MA. 2020. Antimicrobial activity, phytochemical screening of crude extracts, and essential oils constituents of two Pulicaria spp. growing in Sudan. Sci Rep 10: 1-8. DOI: $10.1038 / \mathrm{s} 41598-020-74262-\mathrm{y}$.

Mood SG. 2008. A contribution to some ethnobotanical aspects of Birjand flora (Iran). Pak J Bot 40: 1783-1791.

Mustafa NR, Verpoorte R. 2007. Phenolic compounds in Catharanthus roseus. Phytochem Rev 6: 243-258. DOI: 10.1007/s11101-006-90398.

Nantongo JS, Odoi JB, Abigaba G, Gwali S. 2018. Variability of phenolic and alkaloid content in different plant parts of Carissa edulis Vahl and Zanthoxylum chalybeum Engl. BMC Res Notes 11: 1-5. DOI: 10.1186/s13104-018-3238-4.

Nei, M., Li, W.-H. (1979). Mathematical model for studying genetic variation in terms of restriction endonucleases. Proceedings of the National Academy of Sciences, 76(10), 5269-5273.

Niroula G, Singh N. 2015. Religion and conservation: A review of use and protection of sacred plants and animals in Nepal. J Inst Sci Technol 20: 61-66. DOI: 10.3126/jist.v20i2.13950.

Ntie-Kang F, Njume LE, Malange YI, Günther S, Sippl W, Yong JN. 2016. The chemistry and biological activities of natural products from northern african plant families: From Taccaceae to Zygophyllaceae. Nat Prod Bioprospect 6: 63-96. DOI: 10.1007/s13659-016-0091-9. 
Panhwar AQ, Abro H. 2007. Ethnobotanical studies of Mahal Kohistan (Khirthar national park). Pak J Bot 39: 2301-2315.

Parihar G, Balekar N. 2016. Calotropis procera: A phytochemical and pharmacological review. Thai J Pharma Sci 40.

Poonam K, Singh GS. 2009. Ethnobotanical study of medicinal plants used by the Taungya community in Terai Arc Landscape, India. J Ethnopharmacol 123: 167-176. DOI: 10.1016/j.jep.2009.02.037.

Pudziuvelyte L, Liaudanskas M, Jekabsone A, Sadauskiene I, Bernatoniene J. 2020. Elsholtzia ciliata (Thunb.) Hyl. extracts from different plant parts: Phenolic composition, antioxidant, and antiinflammatory activities. Molecules 25: 1153. DOI: 10.3390/molecules25051153.Pyke, C. R., Condit, R., Aguilar, S., Lao, S. (2001). Floristic composition across a climatic gradient in a neotropical lowland forest. Journal of vegetation science, 12(4), 553566.

Rather MA, Dar BA, Sofi SN, Bhat BA, Qurishi MA. 2016. Foeniculum vulgare: A comprehensive review of its traditional use, phytochemistry, pharmacology, and safety. Arab J Chem 9: S1574S1583. DOI: 10.1016/j.arabjc.2012.04.011.

Rauf A, Jan M, Rehman W, Muhammad N. 2013. Phytochemical, phytotoxic and antioxidant profile of Caralluma tuberculata NE Brown. Wudpecker J PharmPharmacol 2: 21-25.

Sadia S, Khalid S, Qureshi R, Bajwa AA. 2013. Tagetes minuta L., a useful underutilized plant of family Asteraceae: A review. Pak J Weed Sci Res 19: 179-189.

Saeed S, Barozai MYK, Ahmed A, Tareen RB, Begum S, Ali GM. 2016. Analysis of genetic diversity as a key to conserve Berberi. baluchistanica Ahrendt: An endemic species to Balochistan. Production Challenges and Food Security; Proceedings of Pakistan Society for Horticultural Science 2nd International Conference on Horticultural Sciences. Institute of Horticultural Sciences, University of Agriculture, Faisalabad, 18-20 February 2016. [Pakistan]

Saeed S, Barozai YK, Ahmed A, Tareen RB, Ali GM, Shehzad A, Begum S. 2015. Genetic diversity of Ephedra procera from high altitudes of Quetta valley, Balochistan using RAPD and ISSR. Pak J Weed Sci Res 21(2): 163-172

Saleem H, Htar TT, Naidu R, Ahmad I, Zengin G, Ahmad M, Ahemad N. 2019. Investigations into the therapeutic effects of aerial and stem parts of Buxus papillosa CK Schneid.: In vitro chemical, biological and toxicological perspectives. J Pharm Biomed Anal 166: 128-138. DOI: 10.1016/j.jpba.2019.01.007.

Samreen U, Ibrar M, Naveed S, Khatak I. 2016. Ethnobotanical study of subtropical hills of Darazinda, Takht-e-Suleman range FR DI Khan, Pakistan. Pure Appl Biol 5: 149. DOI: 10.19045/bspab.2016.50020.
Sarangzai AM, Ahmed A, Laghari SK. 2013. Traditional uses of some useful medicinal plants of Ziarat District Balochistan, Pakistan. FUUAST J Biol 3: 101-107.

Shuaib M, Ahmed S, Ali K, Ilyas M, Hussain F, Urooj Z, Shah SS, Kumar T, Shah M, Khan I. 2019. Ethnobotanical and ecological assessment of plant resources at District Dir, Tehsil Timergara, Khyber Pakhtunkhwa, Pakistan. Acta Ecol Sin 39: 109-115. DOI: 10.1016/j.chnaes.2018.04.006.

Soliman G, Yusufoglu H, Tatl1-Çankaya I, Abdel-Rahman R, Anul SA, Akaydın G. 2016. Hepatoprotective activities of Lappula barbata and Plantago holosteum against paracetamol induced liver damage in rats and their in vitro antioxidant effects. Planta Med 82: P256. DOI: 10.1055/s-0036-1596397.

Taherian AA, Fakhrian M, Mohammadi A, Amrollahi H, Nazari H. 2018. Anti-inflammatory effect of Launaea acanthodes Gum. J Biochem Tech 2: 92-97.

Tareen RB, Bibi T, Khan MA, Ahmad M, Zafar M, Hina S. 2010. Indigenous knowledge of folk medicine by the women of Kalat and Khuzdar regions of Balochistan, Pakistan. Pak J Bot 42: 1465-1485.

Tosun A, Akkol EK, Bahadır Ö, Yeşilada E. 2008. Evaluation of antiinflammatory and anti-nociceptive activities of some Onosma L. species growing in Turkey. J Ethnopharmacol 120: 378-381. DOI: 10.1016/j.jep.2008.09.007.

Trong Le N, Viet Ho D, Doan TQ, Tuan Le A, Raal A, Usai D, Sanna G, Carta A, Rappelli P, Diaz N. 2020. Biological activities of essential oils from leaves of Paramignya trimera (Oliv.) Guillaum and Limnocitrus littoralis (Miq.) Swingle. Antibiotics 9: 207. DOI: 10.3390/antibiotics9040207.

Tufail M, Hussain K, Nawaz K, Bhatti KH, Yasin G, Ali SS. 2020. Ethnobotanical survey of important wild medicinal plants of Tehsil Gojra, District Toba Tek Singh, Punjab, Pakistan. Ethnobot ResAppl 20: 1-14. DOI: 10.32859/era.20.23.1-14

Whittaker, R. H. (1972). Evolution and measurement of species diversity. Taxon, 21(2-3), 213-251.

Xiong Y, Sui X, Ahmed S, Wang Z, Long C. 2020. Ethnobotany and diversity of medicinal plants used by the Buyi in eastern Yunnan, China. Plant Divers 42: 401-414. DOI: 10.1016/j.pld.2020.09.004.

Yasine R, Khan M, Ghulam A, Irshad M, Abbas Z, Sarfraz R, Khokhar M, Marghub A. 2013. Efficacy of herbicides for control of broad leaf weeds in wheat (Triticum aestivum L.) crop. Sci Int (Lahore) 25: 829832.

Zhu Z, Wang T, Fu D, Gui Y, Wang J, Cui T. 2016. Innovative development path of ethnomedicines: An overview of ethnomedicines in China. Front Med 10: 166-177. DOI: 10.1007/s11684-016-0448-9. 